\title{
Correction to: Effect of Different Forms of Silicon on Growth of Spring Wheat Cultivated in Organic Farming System
}

\author{
Jolanta Kowalska ${ }^{1}$ (D) Józef Tyburski ${ }^{2} \cdot$ Magdalena Jakubowska $^{3} \cdot$ Joanna Krzymińska $^{1}$
}

Published online: 11 March 2020

(C) Springer Nature B.V. 2020

\section{Correction to: Silicon}

$$
\text { https://doi.org/10.1007/s12633-020-00414-4 }
$$

The original version of this article has been published with an error. The first and third author's names are duplicates and the author's name "Magdalena Jakubowska" was unfortunately omitted. Above you can see the correct group of authors.

The original article has been corrected.

Publisher's Note Springer Nature remains neutral with regard to jurisdictional claims in published maps and institutional affiliations.

The online version of the original article can be found at https://oi.org/ $10.1007 / \mathrm{s} 12633-020-00414-4$

Jolanta Kowalska

J.Kowalska@iorpib.poznan.pl

1 Department of Biological Pest Control and Organic Agriculture, Institute of Plant Protection- NRI, 60-318 Poznan, Poland

2 Department of Agrosystems, University of Warmia and Mazury in Olsztyn, 10-719 Olsztyn, Poland

3 Department of Monitoring and Signalling of Agrophages, Institute of Plant Protection- NRI, 60-318 Poznan, Poland 